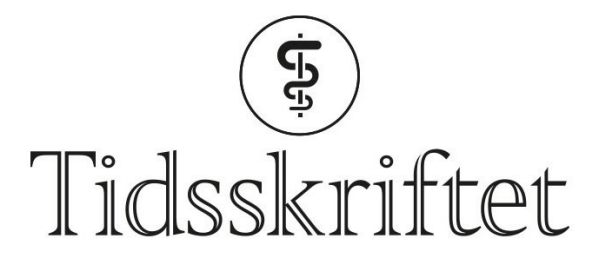

DEN NORSKE LEGEFORENING

\title{
Nivalent HPV-vaksine er best og trygt
}

FRA ANDRE TIDSSKRIFTER

ØYVIND STOPLE SIVERTSEN

Tidsskriftet

Den nye nivalente vaksinen mot humant papillomvirus er mer effektiv og like trygg som den gamle firevalente vaksinen.

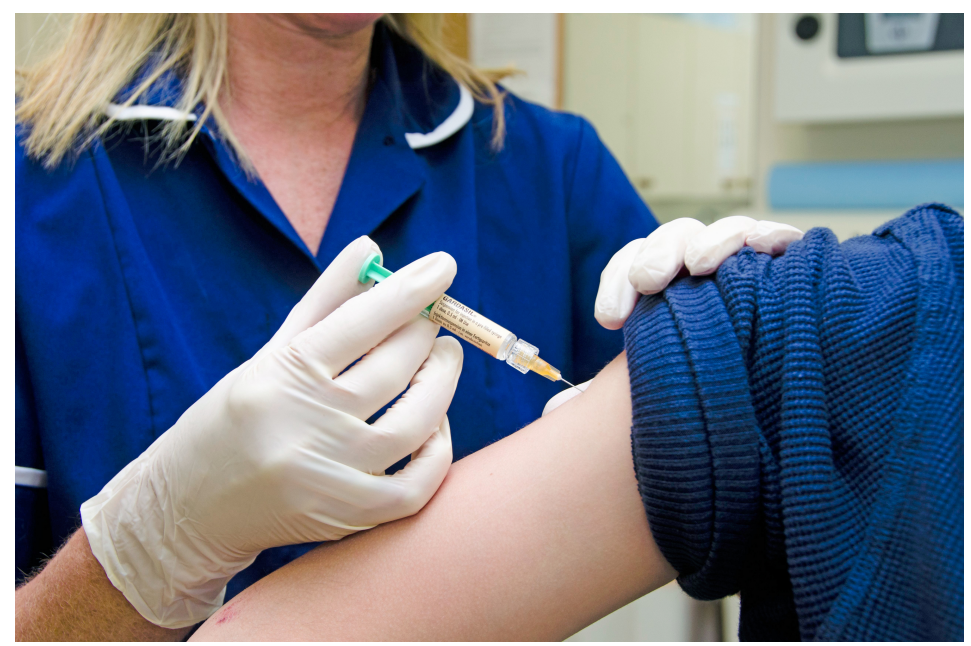

Illustrasjonsfoto: Science Photo Library/NTB scanpix

Den nye nivalente vaksinen mot humant papillomvirus (HPV) er svært lik den gamle firevalente vaksinen, men dekker flere HPV-typer. Vaksinen gir beskyttelse mot både HPV 31 , 33, 45, 52 og 58 i tillegg til HPV 6, 11, 16 og 18.

I en studie som nylig er publisert i The Lancet, ble rundt 14 ooo kvinner i alderen 16-26 år fulgt opp i seks år (1). Omtrent 7 ooo fikk den nye nivalente HPV-vaksinen og omtrent 7 ooo fikk den firevalente vaksinen. I gruppen som fikk den nivalente vaksinen, var det o,5 tilfeller per 10 ooo personår av høygradig cervikal, vulvar eller vaginal dysplasi relatert til de aktuelle virustypene. I kontrollgruppen var det 19 tilfeller per 10 ooo personår. Det var ingen forskjell i bivirkninger. 11 kvinner døde, henholdsvis seks og fem i hver gruppe, men ingen av disse dødsfallene ble vurdert å ha sammenheng med vaksinen.

- Denne studien bekrefter at HPV-vaksinering er trygt og effektivt, og at den nye nivalente HPV-vaksinen gir bedre beskyttelse enn den firevalente, sier Sveinung Sørbye, som er overlege ved Avdeling for klinisk patologi, Universitetssykehuset Nord-Norge.

Han påpeker at mens den firevalente HPV-vaksinen beskytter mot HPV type 16 og 18, som er årsak til $70 \%$ av alle tilfeller av livmorhalskreft, kan den nivalente HPV-vaksinen forebygge opptil go \% av alle tilfeller av livmorhalskreft. 
- Noen vil mene at det er en svakhet ved studien at den ikke hadde en placeboarm med saltvann, men Future II-studien viste at HPV-vaksinering er så effektiv at det er uetisk å ikke tilby aktiv vaksine, sier Sørbye, som mener at studien må få konsekvenser for hvilken vaksine som skal tilbys norske ungdommer.

- Folkehelseinstituttet har tidligere vurdert den bivalente og firevalente HPV-vaksinen som likeverdige når det gjelder forebygging av kreft. Denne studien dokumenterer at den nivalente er bedre enn den firevalente. Det kan derfor være vanskelig å forstå at Folkehelseinstituttet foretrakk den bivalente fremfor den nivalente vaksinen i de to siste anbudene for innkjøp av HPV-vaksine, sier Sørbye.

LITTERATUR:

1. Huh WK, Joura EA, Giuliano AR et al. Final efficacy, immunogenicity, and safety analyses of a ninevalent human papillomavirus vaccine in women aged 16-26 years: a randomised, double-blind trial. Lancet 2017;390: 2143-59. [PubMed][CrossRef]

Publisert: 19. februar 2018. Tidsskr Nor Legeforen. DOI: 10.4045/tidsskr.18.0oo8

(C) Tidsskrift for Den norske legeforening 2020. Lastet ned fra tidsskriftet.no 